\title{
DRAP1 wt Allele
}

National Cancer Institute

\section{Source}

National Cancer Institute. DRAP1 wt Allele. NCI Thesaurus. Code C53103.

Human DRAP1 wild-type allele is located in the vicinity of 11q13.3 and is approximately $2 \mathrm{~kb}$ in length. This allele, which encodes Dr1-associated corepressor protein, plays a role in the modulation of RNA polymerase II activity. 